\title{
Materials Science and Engineering Study Seeks Input from Materials Community
}

Following is a list of topics being considered by the comprehensive Materials Science and Engineering Study commissioned by the National Research Council. Descriptions of the study, progress to date, and panel objectives and members can be found in the May/June 1986 and November/December 1986 issues of the MRS BULLETIN (Vol. XI, Nos. 3 and 6). A report on the MSE Forum conducted by the Materials Research Society at the 1986 MRS Fall Meeting in Boston, MA will appear in an upcoming issue of the BULLETIN.

The MSE Study continues to solicit input from the broad materials science and engineering community and invites their comments and suggestions on any of the topics listed below, sent to the appropriate panel chairman. All submissions will be acknowledged, and an attempt will be made to inform each submitter of how his/her contributions may influence the direction and results of the study. (See the November/December 1986 issue of the MRS BULLETIN, p. 41, for a complete list of MSE Study panel members.)

\section{MSE Study Topics}

\section{Panel 1-Research Opportunities and Needs}

James S. Langer, Chairman

Institute for Theoretical Physics

University of California

Santa Barbara, CA 93106

(805) 961-3247

... Research Opportunities

Synthesis and Processing-Arthur $\mathrm{H}$. Heuer

Characterization-E. Ward Plummer, G. Thomas

Properties and Performance-James Rice, John Hirth

Analysis and Modeling-John D. Joannopoulos

Artificially Structured Materials_-Elias Burstein

Biomaterials-Sumner A. Barenberg

Disordered Materials - Pierre C. Hohenberg

Electronic Materials - Mildred Dresselhaus

Magnetic Materials - Mildred Dresselhaus

Photonic Materials - Robert A. Laudise

Polymeric Materials - James Economy

Structural Materials - John P. Hirth

... Needs of the Industrial SectorGeorge Parshall

Aerospace - Peter Cannon

Automotive - Christopher Magee
Biomaterials - Sumner A. Barenberg

Chemical, Ceramics, Polymers George S. Hammond

Communications - Robert A. Laudise

Electronics - Robert Stratton

Energy - Robert I. Jaffe

Metals - Ian Hughes

. Needs of the Federal Sector-James O. Stiegler

Panel 2 - Exploitation of Materials Science and Technology for National Welfare

Alan C. Chynoweth, Chairman

Vice President, Applied Research

Bell Communications Research, Inc.

Morris Research and Engineering Center

435 South Street

Morristown, NJ 07960

(201) $829-2100$

This panel is attempting to assess the impact that materials science and technology can have on U.S. national security and competitiveness in the global economy. The panel is identifying factors particularly important in achieving effective innovations - especially the successful and rapid commercialization of new products that are based on advances in materials science and technology.

... What lessons concerning institutional and support mechanisms can be learned from examples of successful and unsuccessful efforts to achieve significant innovations?

... What existing institutional and support mechanisms are particularly important in achieving effective and rapid innovations, and which need to be strengthened?

.. What new institutional and support mechanisms can be recommended to achieve effectlve and rapid innovations?

To date, much of the discussion has focused on the successes and failures of specific technologies and materials. In addition, there has been an attempt to determine if the institutional setting affects the ability to develop and implement new technology and materials. Panel 2 has also conducted two workshops to broaden the data base for making conclusions.

Topics considered at the first workshop, Case Studies of Selected Materials and Technologies, October 24, 1986 include:

Liquid Crystals

Intermetallic Compounds

Carbon Fibers

Polymers for VLSI Processing

Intelligent Materials Processing

Optical Fibers

Structural Ceramics for Heat Engines

\section{NdFeB Magnets}

Magnetic Recording for Data Storage

Infrared Detectors

Topics considered at the second workshop, Examinations of Selected Institutions and Institutional Factors, December 9, 1986 include:

... Institutions

Los Alamos National Laboratory

Semiconductor Research Corporation

Bell Communications Research

Microelectronics Corporation

Air Force Manufacturing Technology Programs

... Institutional Factors

Legislation and Policy

Vertical Integration

Venture Capital

Role of Professional Societies

In addition to the workshop topics, Panel 2 has considered the following issues:

... Development of Technology - Where do ideas originate? Who champions them? Who determines commercial value?

. Funding of R\&D Which Culminates in New Technologies and Products funding sources, expectations (payoff periods, etc.), how to determine quality of $R \& D$, proprietary versus public research, role of universities,

... How has MSE Fared/Contributed?

... What Needs to be Done?

From these deliberations some tentative conclusions and thoughts have emerged:

(1) Short-term return focus hurts industrial competitiveness.

(2) National security should not be confused with national competitiveness.

(3) Decentralized profit responsibility hurts information/technology sharing and transfer.

(4) Vertical integration can be helpful.

(5) Entrepreneurship and startups may be overrated concepts.

(6) Is too much emphasis placed on proprietary and classified research?

Panel 3-International Cooperation and Competition

Lyle H. Schwartz, Chairman

Center for Materials Science

National Bureau of Standards

Building 223, Room B-308

Gaithersburg, MD 20899

(301) 921-2891

... Nature of MSE Abroad

Competitive Factors

Comparative Analysis

... Case Studies of Foreign MSE Impact Continued 
on U.S. Industrial Technologies

.. Structural Materials in Commercial Aircraft

Manufacturing of Steel-Richard J. Fruehan

Information/Communication MaterialsVLSI-C. Peter Flynn

Magnetic Storage - Robert White

Ceramic Heat Engines - Arthur Diness

Engineering Plastics - Rudolph Pariser

Zeolite as Catalyst — Gabor A. Somorjai

Panel 4-Research Resources in MSE

Terry L. Loucks, Chairman

Norton Company

1 New Bond Street

Worcester, MA 01606

(617) 853-1000

Federal Research Program - Bhakta Rath

Major Equipment Installations Martin Blume

Intermediate-Scale Facilities - John Gilman

Individual Principal Investigators Isaac F. Silvera

Advanced Manufacturing and Processing - Terry L. Loucks

Advanced Instrumentations - J. David Litster

Advanced Processing of ElectronicsRobert S. Bauer, B.R. Appleton

\section{Panel 5-Education in MSE}

I. Melvin Bernstein, Chairman

Department of Metallurgical Engineering and Materials Science

Carnegie Mellon

Pittsburgh, PA 15213

(412) 268-2700

Composition and Profile of Education in MSE

Educational Background for Those Working in MSE

Undergraduate Education in MSE for Materials Majors

Undergraduate Education in MSE for Nonmaterials Majors

Education in MSE at the Graduate Level, in MSE and in Other Departments

Interdepartmental MSE Educational Programs

University/Industry Interactions

Research/Education Interactions

Supply and Demand for Materials Graduates

Facilities, Equipment, Resources for Education

Future Needs, Opportunities, and Directions for MSE

\section{Communications on the Materials Science and Engineering Study}

This book is a compilation of all papers contributed to the Materials Research Society which pertain to the Materials Science and Engineering Study.

Price: $\$ \mathbf{8 . 0 0}$

Order from:

Publications Department

Materials Research Society

9800 McKnight Road, Suite 327

Pittsburgh, PA 15237

Telephone (412) 367-3012

\section{Advancing Materials Research}

\section{From the National Research Council Published by National Academy Press}

Highlights ancient and recent advances in materials science and engineering, provides a look at the current status of materials research, and identifies major policy issues for corporate, academic and governmental services.

MRS Members: $\$ 42.50$

U.S. Nonmembers: $\$ 47.50$

Order from:

Publications Department

Materials Research Society

9800 McKnight Road, Suite 327

Pittsburgh, PA 15237

Telephone (412) 367-3012 